\title{
Developing critical literacy in a PARFOR teaching practicum module
}

\section{Desenvolvendo o letramento crítico em um módulo de prática de ensino do PARFOR}

\author{
William Mineo Tagata* \\ Universidade Federal de Uberlândia \\ Uberlândia - Minas Gerais / Brasil
}

\begin{abstract}
This paper aims to describe a distance education experience that took place in a teaching practicum module of PARFOR (National Plan for Educating Primary and Secondary School Teachers) at the Federal University of Uberlândia. With the aim of promoting a discussion about race and ethnicity in Brazil, the materials and activities of this module were devised in a critical literacy perspective (KNOBEL; LANKSHEAR, 2011; COPE; KALANTZIS, 2012). The paper begins with a discussion of relevant issues concerning learning and literacy in distance education today, and then moves on to a brief description of this teaching practicum module. After an analysis of two tasks from this module, we conclude by reflecting on some of the shortcomings regarding the implementation of the course, and suggesting ways in which they could be overcome.
\end{abstract}

KEYWORDS: critical literacy; distance education; teaching practicum.

RESUMO: Este artigo objetiva descrever uma experiência de educação a distância que aconteceu em um módulo de prática de ensino do PARFOR (Plano Nacional de Formação de Professores da Educação Básica) na Universidade Federal de Uberlândia. Com o objetivo de promover uma discussão sobre raça e etnicidade no Brasil, os materiais e atividades desse módulo foram elaborados em uma perspectiva de letramento crítico (KNOBEL AND LANKSHEAR, 2011; COPE AND KALANTZIS, 2012). O artigo começa com uma discussão de questões relevantes sobre aprendizado e letramento na educação a distância atualmente, e em seguida faz uma breve descrição desse módulo de prática de ensino. Após uma análise de duas tarefas desse módulo, concluímos com uma reflexão sobre algumas das dificuldades em relação à implementação do curso, e sugerindo formas em que elas podem ser superadas.

PALAVRAS-CHAVE: letramento crítico; educação a distância; prática de ensino.

*wtagata@gmail.com 


\section{Introduction: learning and literacy in distance education}

At present, distance education in Brazil seems to be increasingly reliant on the use of new information and communication technologies like the Internet. According to Paiva (1999, 2015), such technologies have paved the way for flexible learning, available to a great many people from different geographic locations who can benefit from enhanced graphic design and ample interactivity, learning at their own pace and able to make choices as to when and where to learn. As a result, learners are becoming more autonomous and able to engage in collaborative learning with their peers and teachers, who are no longer seen as their sole sources of information or knowledge. This raises a number of questions regarding the effects of technology on learning, and its consequences for literacy acquisition. For example: how does technology change the way we make meanings? How can it cha(lle)nge our present representations of distance education, language and literacy? What are the social, epistemological, political and ethical implications of new information and communication technologies in distance education? What kinds of literacy are developed through the use of these technologies, or what kinds of literacy practices do they involve? In the case of digital literacy, how does it differ from other literacies in terms of how meanings are made? Can new information and communication technologies create opportunities for the development of critical literacy? How? To what extent does working with digital technologies require the development of new mindsets, in order to avoid what Knobel and Lankshear (2011) called the "old wine in new bottles" effect? How do these new technologies and related literacies shape our identities? How do they change (or not) teachers' and students' roles in education and more generally in the meaning making process?

These questions are central to the kind of research on the relations among technology, learning and literacy carried out by researchers, such as Braga (2014), Gee (2003), Knobel and Lankshear (2011), Paiva (2015), Souza (2007), Snyder (2002), and Ribas and Tagata (2015), among others. According to Lankshear, Snyder and Green (2000), digital technologies, unlike other kinds of technology involved in education, highlight the sociocultural aspect of learning, focusing not on schools or students, but "on human lives seen as trajectories through numerous social practices across a range of institutions" (p.44). According to the authors, this calls for a "3D approach" to literacy education involving new technologies - 
an approach that seeks to consider the operational, cultural and critical dimensions of learning, seen as social practice. Rather than merely focusing on the technical competence - the "how-to" knowledge - we should always contextualise this competence "in ways that pay due attention to matters of culture, history and power and recognise that it is counterproductive to start with issues of skill or technique, outside an authentic context of situated social practice" (2000, p. 45). In this sense, Lankshear, Snyder and Green subscribe to a sociocultural view of learning and literacy that acknowledges the embeddedness of language in political, cultural and historical contexts - similarly to what Belloni (2002) suggests in her critique of what she terms "technocratic proposals" in education. According to Belloni, educational policies for the use of digital technologies in distance education should not fail to address the social, political and historical issues surrounding the uses of technology - in other words, the "social ground" on which these policies are to be implemented. This means that technology is not neutral; rather, it is always subject to specific discourses circulating in a particular context and the ideologies underlying them, and inscribed in given Discourses, ${ }^{1}$ which constitute the "social ground" upon which educational policies are formulated. Failure to take account of this social ground, according to the author, can compromise the success of such proposals for distance education, especially if they only value the technical competence necessary for using technology.

This need to consider the operational, cultural and critical dimensions of learning, in the context of distance education mediated by new information and communication technologies, was a driving force behind the elaboration of the activities and materials of a module offered as part of a PARFOR course. In the next section, we examine this module in detail.

\section{The teaching practicum of PARFOR}

The accessibility and flexibility of the Internet paved the way for the development of online courses as part of teacher education programmes. One such course is PARFOR, or the National Plan for Educating Primary and Secondary School Teachers. Implemented on a national level by CAPES, an organ of the Ministry of Education and Culture in Brazil, and with the participation of local and national education authorities and specialists,

${ }^{1}$ For the distinction between discourse and Discourse, see Gee (2010). 
PARFOR aims to offer public school teachers the opportunity to study for their first degree in the subject areas in which they are already working in public schools, even though they may not have obtained a formal degree from university. Thanks to the collaboration among CAPES, municipal and state education authorities, and federal universities in Brazil, PARFOR has made it possible for practising public school teachers throughout the country to pursue the professional qualification that is required by current legislation, and that is presently being offered by higher education institutions in Brazil, like the Federal University of Uberlândia (UFU), for example, where this study was conducted. In this university, distance education is thought of as a means through which to provide free and quality education committed to social inclusion. At present, five courses are being offered by UFU, as part of its endeavour to consolidate distance education: Education, Maths, English, Spanish and Public Administration.

In this paper we look at the English online graduate course, ${ }^{2}$ which started in 2012 and finished in 2015. It was a four year course totalling 2,865 hours, and was aimed at primary and secondary teachers who had been working in public schools for at least three years, in compliance with the National Policy for Teacher Development in Basic Education. ${ }^{3}$ The course was based on a view of distance education as a new mode of building, developing and socialising knowledges, as well as promoting social inclusion and overcoming distance and time constraints that could hinder the access of many to education. In this sense, distance education is not regarded as a mere application of traditional face-to-face practices to online environments, but as a modality of its own, with specific interaction patterns among teachers, coordinators, tutors and students, or specific literacy practices determined by such factors as netiquette, for example. As a result, it was expected that participants should be able to develop a new educational mindset, capable of conceiving new ways of knowledge building.

According to the course curriculum, by the end of this 4-year-distance course, students were expected to present a number of characteristics:

\footnotetext{
${ }^{2}$ Unlike some other federal institutions where PARFOR is also being implemented, where students take some modules via online distance learning and others via face-toface classes, in the Federal University of Uberlândia, all courses are offered exclusively in the online distance modality.

3 This national policy was developed as a result of Brazilian law 6755, ratified on January 29, 2009.
} 
- Intellectual autonomy to develop a sociohistorical vision of teaching, so as to become a critical, ethical and creative professional, able to understand, act upon and change reality;

- Ability to establish relationships based on cooperation and solidarity;

- Ability to produce and socialize knowledge and technologies;

- Ability to understand the demands of social groups and communities in relation to socioeconomic, cultural, political and organizational problems, so that available resources can be used rationally, without jeopardizing nature's balance;

- Professional training in order to engage in ongoing development and promote innovation in the workplace;

- Mastery of skills and knowledge specific to the subject in question, as well as corresponding methodologies, so as to deal with a number of teaching and learning situations;

- Ability to help in the design of the political and pedagogical project of the school where the teacher works.

While the PARFOR English course at this federal university was offered entirely in an online, distance modality, at the same time, students were supposed to attend a face-to-face meeting at the end of the semester in order to take their final, written test. In addition, there were three other compulsory face-to-face meetings: the opening meeting at the beginning of the course, as well as two seminars: one in the middle of the course, and the other at the end. Doing subjects like Speaking, Listening, Reading, Writing, Academic Discourse Practices, Everyday Discourse Practices, American Literature, Brazilian Sign Language, Media Studies, among others, students could count on such resources as printed materials, videoconferences and introductory videos recorded by the professors in charge of the subjects, the Moodle learning environment, chat sessions with course tutors, and a Forum where relevant topics could be discussed.

In this paper, we look at the third module of the Teaching Practicum component ${ }^{4}$ of the course. Totalling 100 hours, this module was intended to help students to make the transition from theoretical knowledge that had

${ }^{4}$ The Teaching Practicum component consists of four modules, each of which was 100 hours long. 
been acquired during the course to actual classroom practice, moving beyond the walls of the classroom by getting them to observe lessons, devise English teaching activities and lesson plans and implement them, and share their experiences in online Forums, interacting with their peers and the course tutor, under the guidance of professors who were in charge of elaborating materials, supervising the tutors' work and giving videoconferences, as well as assessing students' production and marking end of term tests. By the end of the course, students were able to engage in a process of critical thinking about what goes on in actual classrooms, and what they could do as researchers of their own practices and political agents of social change.

The third module of the Teaching Practicum was devised by professor Fernanda Ribas and myself. For this module, we chose to devise reading, listening and writing tasks on the theme of cultural diversity, as well as ethnicity and race relations in Brazil, in compliance with Brazilian law. ${ }^{5}$ It seemed to us that the best way of approaching the theme would be from a critical literacy perspective (COPE; KALANTZIS, 2012; LANKSHEAR; SNYDER; GREEN, 2010), mainly for two reasons. First, given that the aim of the Teaching Practicum is to help students make the transition from theory to practice, and become more critical, ethical and creative professionals and thinkers, a critical literacy perspective would enable student teachers to realize that the world of language, and hence literacy, is subject to critical examination, and thus open to change. As Lankshear, Snyder and Green (2000) put it,

The 'critical' dimension involves awareness that all social practices, and hence all literacies, are socially constructed and 'selective': they include some representations and classifications - values, purposes, rules, standards, perspectives - and exclude others. To participate effectively and productively in any literate practice, people must be socialised into it. But if individuals are socialised into a literacy without realising that it is socially constructed and selective, and also that it can be acted on and transformed, they cannot play an active role in changing it. The critical dimension of literacy is the basis for ensuring that individuals are not merely able to participate in an existing literacy and make meanings within it, but also that, in various ways, they are able to transform and actively produce it. (LANKSHEAR; SNYDER; GREEN, 2000, p.31)

${ }^{5}$ Brazilian Federal Law 10.639, from January 09, 2003. 
In a similar fashion, Cope and Kalantzis (2012) also point out that literacies are socially constructed, and emphasize students' potential to take a critical stand on the meanings and representations that we are faced with, underscoring their roles as active designers or creators of meaning:

The aim of critical literacies is to help learners understand the ways things are constructed in the world by people's values and actions. Its assumption is that the world of learning is not simply a series of rules to be obeyed, facts to be learned and knowledge authorities to be followed. In textual terms, a critically literate person identifies relevant and powerful topics, analyses and documents evidence, considers alternative points of view, formulates possible solutions to problems and perhaps also tries these solutions, comes to their own conclusions and makes well-reasoned arguments to support their case. (COPE; KALANTZIS, 2012, p.149)

Another reason why it would be interesting to work in a critical literacy perspective was the fact that this module centred around a discussion about ethnicity and race relations and cultural diversity in Brazil, as depicted in language and literacy practices. This would require a critical examination of how language constructs our racial and ethnic identities, forming the basis upon which racism and other discriminatory practices are grounded. Therefore, we expected to raise students' awareness that all identities are constructed in and through Discourses (GEE, 2010), understood as social practices combining beliefs, actions, values, world views, goals and purposes, conventions, in addition to ways of speaking, reading and writing, all of which permeated by power relations. This in turn can enable us to investigate how specific discourses (GEE, 2010) may be patronizing, forcing us into ethnic or racial pigeonholes and making assumptions about our world views and attitudes on the basis of our physical appearance. More importantly, a critical literacy perspective is empowering, in that it helps us realize that we can act upon these discourses and change them in ways that our identities are depicted more favourably. In this sense, critical literacy makes it possible to redress unequal race relations and avoid discriminatory practices. By encouraging students to develop what Cope and Kalantzis (2012) termed "inward looking", or what Souza (2011), described as "listening to oneself while listening", critical literacy invites us to examine the ways in which we construct our own interpretations of the world, which are always necessarily contingent and context related. This can help us acknowledge and accept 
different perspectives and realize that our interpretations may be different from and even offensive to other racial, ethnic and cultural groups.

In the next section we present two tasks devised for the third module of the Teaching Practicum, which illustrate the principles of critical literacy outlined above.

\section{Critical literacy and ethnicity and race relations}

The Moodle learning environment is the most commonly used resource by PARFOR students, tutors and supervising professors at the federal institution where this case study was conducted. One of its most useful tools is the Forum, where students can post their answers to the course tasks as well as receive feedback from their peers and tutors. This section presents two examples of such tasks. Like some other tasks in the third module of the Teaching Practicum, students could choose to post their answers in English or in Portuguese. This was done to encourage as many students as possible to participate, regardless of their linguistic proficiency in English. In this manner, their lack of proficiency in English would not act as a deterrent to participation in Moodle activities.

In Task 26, students were asked to watch a short film available on YouTube and answer two questions about it. Of all the 27 students taking the third module, only 5 posted their answers on Moodle. Here is the task, followed by the students' answers:

TASK 26 (Moodle Forum):

Watch a short film called "Strangers" (available at https:/ / www.youtube. $\mathrm{com} /$ watch? $\mathrm{v}=\mathrm{RpjHSiQLPmA}$ ) and answer the following questions. Remember to post your answers in the Forum (Task 26):

1. What is the movie about? Which ethnic and racial issues does it touch upon?

2. If you used the movie in one of your English lessons at a public school, which questions would you ask your students to answer shortly after the movie? Make at least TWO questions in English to start a debate about ethnic and racial issues in order to promote students' critical literacy.

Post your answers in the Forum. Then comment upon your colleagues' posts. 


\section{Forum: ${ }^{6}$}

Here are the answers posted by the five students in the Moodle

\section{Student 1:}

1. A miscigenação americana; o preconceito racial e o preconceito religioso. $^{7}$

2. Attention dear students: Now you will write a piece that you guys understand that micro film. And then will respond: Do you have a religion? Which? And what do you think about religious racism? Do you think there is this kind of racism in Brazil?

Student 2:

O filme fala do racismo e preconceito religioso. Eu provocaria um debate onde a reflexão e a análise crítica fosse livre, e a troca de idéias fosse levantada. Qual a religião de cada um e como cada um relaciona com a religião e a cultura do outro. Finalizando com confecção de texto e leitura e reflexão do filme. ${ }^{8}$

Student 3:

1. muçulmanos judeus racismo preconceito diferenças religiosas ${ }^{9}$

2. Write a text telling you understood of the movie. Have you seen any scenes that seem racist? Which? In the film appear Religions? How many? Which?

Student 4:

O filme se passa num metrô, aborda a intolerância racial e religiosa sem nenhuma troca de palavras, o tempo todo, a mensagem é transmitida através de expressões faciais, sinais e símbolos. Um árabe está lendo o jornal, quando um judeu senta-se próximo a ele e expõe sua estrela de Davi, mas os dois são afugentados pelo medo ao entrar no vagão um grupo de skinheads. O judeu esconde sua estrela de Davi enquanto o

\footnotetext{
${ }^{6}$ We opted not to make any changes to the students' answers in terms of grammatical accuracy or content. Again, students could choose to post their answers in English or in Portuguese.

${ }^{7}$ My translation: American miscigenation; racial prejudice and religious prejudice.

${ }^{8}$ My translation: The film is about racism and religious prejudice, I would start a debate where reflection and critical analysis were free, and the exchange of ideas encouraged; which is each student's religion and how each student relates to another student's religion and culture. Ending with text production and reading and reflection about the movie.

${ }^{9}$ My translation: Muslims jews racism prejudice religious differences
} 
grupo se dirige ao árabe, mas quando toca o celular do judeu, a música é típica de sua religião e o grupo passa a perseguir tanto o árabe, quanto o judeu que conseguem fugir. Em primeiro lugar deixaria que os alunos explicassem o que entenderam, depois iria contextualizar o filme, acredito que levaria um resumo de cada grupo deixando claro o quanto são intolerantes e extremistas, para que ao final entendessem o quanto foi difícil para o árabe e o judeu se juntarem e fugirem do grupo mais forte. ${ }^{10}$

\section{Student 5:}

1. Preconceito racial e religioso. ${ }^{11} 2$. As a situation of fear can overcome the prejudice and race hatred? The intolerance between Arabs and Jews.

It still remains to be seen why so few students ( 5 out of 27 ) posted their answers to this task. One of the reasons for this may be that no marks or grades were given for its completion, which could have led students to focus only on evaluation tasks like Task 27 below. If that was indeed the case, students behaved as if they were in face-to-face settings, where participation often occurs when they are rewarded for it, for example, by getting marks. Also, not all the students followed the instructions to Task 26. The second part of the task required them to make at least two questions so as to provoke a debate about racial and ethnic issues in the light of critical literacy, as was the case of students 4 and 5, who failed to post these questions. Another point worth mentioning is the fact that some students appeared to have a low proficiency in English, despite having been attending the course for almost 4 years. This can be seen in the answers of student 1 ("Now you will write a piece that you guys understand that micro film. And then will respond"), student 3 ("Write a text telling you understood of the

\footnotetext{
${ }^{10} \mathrm{My}$ translation: The film is set in a subway, it's about racial and religious intolerance with no exchange of words, the entire time the message is conveyed through facial expressions, signs and symbols. An Arab is reading the paper when a Jew sits close to him and shows his Star of David, but they're both scared when a group of skinheads boards the train. The Jew hides his Star of David while the group turns to the Arab, but when the Jew's mobile rings, the ringtone is typical of his religion and the group starts to chase both the Arab and the Jew, who manage to escape. First I would let the students explain what they understood, afterwards I would contextualise the film, I think I would collect a summary from each group, making it clear how intolerant and extremist they are, so that in the end they could understand how difficult it was for the Arab and the Jew to get together and escape the stronger group.
}

${ }^{11}$ My translation: Racial and religious prejudice. 
movie"; "In the film appear Religions?") and student 5 ("As a situation of fear can overcome the prejudice and race hatred?", instead of "How can fear overcome prejudice and social hatred?").

In the case of student 4 , there seem to be traces of a traditional, topdown or "banking education" (FREIRE, 2005), as student 4 appears to adopt a position of knowledge authority in the classroom: "Em primeiro lugar deixaria que os alunos explicassem o que entenderam, depois iria contextualizar o filme, acredito que levaria um resumo de cada grupo deixando claro o quanto são intolerantes e extremistas. ${ }^{12}$ " In this student's view, the teacher is in charge of the teaching and learning process, having the right answers or appropriate knowledge to impart to his or her students. This suggests that these PARFOR students may not have fully understood the concept of critical literacy, and how it can promote collaboration between students and teachers in the classroom in the process of cobuilding knowledge that is relevant to their social and historical context. There appears to be a similar problem in the following examples, taken from Forum 27.

In Forum 27, students were asked to plan an activity for teaching English to secondary school students in public education. The aim of this activity was to spark a debate about ethnicity and race relations, reflecting the principles of critical literacy as far as possible. In addition, students were asked to explain in what ways they believed the activity would help to develop public school students' critical literacy, bearing in mind the theorists that they had studied at the beginning of the module. ${ }^{13}$

This time, 18 out of 27 students posted their answers on Moodle, probably owing to the fact that their answers would be commented upon and marked by the course tutors. Here are two examples of activity plans. Again, in this task students could choose to post their plans in Portuguese or in English:

\footnotetext{
${ }^{12} \mathrm{My}$ translation: First I would let the students explain what they understood, afterwards I would contextualise the film, I think I would collect a summary from each group, making it clear how intolerant and extremist they are.

${ }^{13}$ Freire (2005), Souza (2011), Knobel and Lankshear (2011) and Cope and Kalantzis (2012), among others.
} 


\section{Task 27 (Moodle Forum)}

Student 6:

Procedimentos: $:^{14}$

1. Mostrar um video clipe da música "Black or White" de Michael Jackson.

2. Verificar se algum aluno já conhece a música e/ou o cantor.

3. Solicitar que expressem o que entenderam do vídeo clipe.

4. Questionar sobre o significado da música, as imagens que aparecem no vídeo clipe.

5. Indagar a respeito dos objetivos do cantor quando fez esse trabalho.

6. Apresentar quatro fotos de épocas diferentes de Michael Jackson e perguntar se os alunos têm alguma informação sobre as mudanças físicas do cantor.

7. Explicar sobre a doença vitiligo, que foi o motivo alegado pelo cantor para justificar seu embranquecimento.

${ }^{14}$ My translation:

Steps of the lesson:

1. Play the videoclip of the song "Black or White", by Michael Jackson.

2. Check if any student knows the song and/or the singer.

3. Ask them to say what they understood from the videoclip.

4. Ask them about the meaning of the song, the images from the videoclip.

5. Ask students about the singer's goals when he wrote this song.

6. Show four pictures of Michael Jackson in different moments and ask students if they know anything about the singer's physical changes.

7. Explain about vitiligo, which was the reason given by the singer for his whitening.

8. Discuss what leads someone to go through so many surgeries to change his or her own face.

9. Ask students about racism in Brazil, whether in their context they feel they have to turn white to be accepted in society.

10. Analyse the poster "Don't matter if you are, Black or White" (sic) and ask students' opinions about the truthfulness of this statement in their contexts.

11. Hand out a copy of the lyrics with gaps to be filled by the students.

12. Ask students to listen to the song and fill in the gaps while watching the videoclip again.

13. After making sure that most students managed to complete the lyrics, teacher plays the clip pausing after each stanza so that students can say the words for each gap.

14. Write the missing words on the board.

15. Sing the song following the lyrics. 
8. Problematizar o que leva um sujeito a passar por tantos processos cirúrgicos a fim de modificar seu próprio rosto.

9. Solicitar que respondam sobre o processo de racismo no Brasil, se no contexto vivenciado por eles há algum momento em que necessitam embranquecer-se para serem aceitos na sociedade.

10. Analisar o cartaz "Don't matter if you are, Black or White" (sic) e saber a opinião dos alunos sobre a veracidade dessa frase no contexto vivido por eles.

11. Entregar uma cópia da letra da música com lacunas a serem preenchidas por cada aluno.

12. Solicitar que acompanhem a música e completem as lacunas ao assistirem ao vídeo clipe novamente.

13. Após a confirmação de que a maioria conseguiu completar a letra da música, assistir ao vídeo clipe pausando a cada estrofe a fim de que os alunos informem as palavras para o preenchimento das lacunas.

14. Escrever no quadro as palavras que estavam faltando.

15. Cantar a música acompanhando a letra.

Student 7:

Procedimentos: $:^{15}$

${ }^{15}$ My translation:

1. Present the theme by asking "What is racism?"

2. Ask students to mention existing kinds of racism.

3. Show the advertisements (available at http://www.astrologer.com/pics/ cartoons/racism.gif; http:/ /www.ethicsingraphicdesign.org/wp-content/ uploads/2015/02/3-hearts.jpg; https://s-media-cache-ak0.pinimg.com/736x/6e/ a2/8e/6ea28ea49b55976f20735a3c03948c3f.jpg; https:/ / s-media-cache-ak0. pinimg.com/236x/27/02/0a/27020afe07401136b2eb5a14cab2d0fe.jpg) and ask students what they understood, how they feel about these adverstisements, whether they understood what's written in them and explain unknown words.

4. Ask students if they remember any other advertisements that allude to racism.

5. Ask them if they have suffered racism or if they know someone who does or already has.

6. Ask what should be done to put an end to racism once and for all.

7. End the discussion with the song We are the World and tell them a little about the story of the song and ask whether they've heard it before.

8. Play the videoclip of the song, asking them to first watch the clip for the feel of the message.

9. Ask what they thought, encouraging them to say what the song is about.

10. Hand out a copy of the lyrics and encourage students to sing along while watching the clip again. 
1. Introduzir o tema com a pergunta: What is racism?

2. Pedir para que os alunos citem os tipos de racismo que existem.

3. Apresentar os anúncios (http://www.astrologer.com/pics/cartoons/ racism.gif; http://www.ethicsingraphicdesign.org/wp-content/ uploads/2015/02/3-hearts.jpg; https://s-media-cache-ak0.pinimg. com/736x/6e/a2/8e/6ea28ea49b55976f20735a3c03948c3f. jpg; https://s-media-cache-ak0.pinimg.com/236x/27/02/0a/ 27020afe07401136b2eb5a14cab2d0fe.jpg) e questionar os alunos sobre o que entenderam, qual o sentimento que eles têm com relação àquele cartaz, se entenderam o que está escrito nele e explicar alguma palavra não conhecida.

4. Perguntar se eles se lembram de algum outro anúncio que faz alusão ao racismo.

5. Perguntar se já sofreram racismo ou se conhecem alguém que já sofreu ou sofre.

6. Questionar o que se deve fazer para acabar de vez com o racismo.

7. Finalizar a discussão com a música We are the World e contar um pouco da história da música e perguntar se eles já a ouviram antes.

8. Passar o videoclip da canção, pedir que nesse primeiro momento eles apenas vejam o videoclip e sintam a mensagem transmitida.

9. Perguntar o que eles acharam, instigando-os a falarem sobre o que dia (sic) a música.

10. Entregar uma cópia da letra da música com a tradução e estimular os alunos a cantarem a canção passando o clip novamente.

On the one hand, both activity plans seem to lend themselves to an interesting discussion of how ethnic and racial identities are represented in the media, and their effects on the formation of discourses and identities. The advantage of using visual or multimodal materials, such as videoclips and advertisements, is that they can certainly help engage students more promptly in such discussions, as they are likely to understand the topic of discrimination more easily, and ponder controversial issues such as the ideology of whitening and how people's attitudes contribute to the reinforcement of a racial hierarchy and discrimination in Brazil, as is the case of the activity plan devised by student 6 . Yet it is unclear how the song/videoclip chosen by student $7-$ "We are the world", a charity single written for African famine relief in the eighties - may be related to the topic of race and ethnicity.

On the other hand, neither of the activity plans explains how the materials could be exploited in a critical literacy perspective or comment 
in what ways they could ground a discussion about race and culture. While both activity plans create opportunities for debating the issue of racism - by encouraging students to give their own definitions of racism and relate the topic to their own personal experiences, it is still unclear how this debate would be carried out in such a way that it might help them to examine how their beliefs or viewpoints are constructed in and through discourse. Bearing in mind what the aforementioned theorists - namely Lankshear, Snyder and Green (2000), Souza (2011), and Cope and Kalantzis (2012) - define as critical literacy, it remains to be seen how these activity plans could promote a critical debate about ethnicity and race relations to enable its participants to reflect upon their views of these relations, as well as their own racial identities, to realize how these identities and relations are contingent or context dependent, and to actively transform the literacy practices in which these racial and ethnic representations are embedded.

Whilst the discussion questions posted in Forum 26 and the activity plans in Forum 27 seemed pertinent to the topic of race and ethnicity, there is no guarantee that they could foster critical literacy. In order for this to happen, some of the assumptions underlying the choice of materials and design of activity plans would have to undergo a critical examination. One of these assumtions is that teachers are still knowledge holders who are expected to impart this knowledge to students. Why would teachers have to explain the gist of the short film in Task 26, or assume that students do not know what vitiligo is? Why not let students choose songs about race and ethnicity or bring their own memes about discrimination? Why ask students to fill in the gaps while watching the videoclips? What can students actually gain from gapfill activities, at the end of which it is always up to the teacher to impart the correct answers? Why would student teachers only complete tasks devised for evaluation, like Task 27? As mentioned above, only 5 out of 27 students completed Task 26, which was not meant for evaluation. If all these questions remain unexamined, traditional power relations, in addition to student and teacher roles, can end up being reinforced, with the former seen as mere recipients of formal instruction and the latter construed as knowledge holders, in what Freire (2005) considered a "banking model" of education, as already mentioned above. 


\section{Final remarks}

In her comprehensive and insightful essay about distance education, Belloni (2002) suggests that one of the biggest challenges facing tertiary education in Brazil is to offer opportunities for continued professional development to meet the demands of a post-Fordist job market, without losing sight of the importance of forming critical citizens capable of reflecting on and changing the world - in other words, a critically literate citizen. In order to achieve this, according to Belloni, it is of paramount importance that educational systems be able to innovate their contents and methodologies, creating new solutions to both old problems as well as those resulting from the implementation of new communication and information technologies.

In the case of our PARFOR distance education - of which, it must be noted, the examples given here are only a small fragment - some of the old problems from the face-to-face, classroom interaction still persisted, such as the prevalent assumption that teachers should still be in charge of materials selection and knowledge transmission. Another problem that seemed to persist was the fact that most of the PARFOR students in the third module of the Teaching Practicum only completed the tasks that would be graded or marked, leaving aside other, equally important tasks. This also involved a number of web conferences carried out by us in an attempt to answer students' questions, and to provide and obtain feedback, which were poorly attended - on average, only $10 \%$ of the students attended these webconferences. Unfortunately, we have yet to ascertain the reasons for this, which is imperative to improving the quality of future distance education programmes. Moreover, one of the problems resulting from the use of digital technologies is the low level of digital literacy on the part of some students, unable to perform relatively simple tasks, such as uploading files in Moodle forums. In addition, in some cases, technical problems, such as slow connection speed, may have prevented students from completing course assignments.

Despite all the problems faced by our PARFOR students, it is our belief that there is room for critical literacy development in distance education. This belief is grounded on successful experiences involving the use of new information and communication technologies in tertiary education, such as that described by Ribas and Tagata (2015). In their study, the authors describe two different instances of the use of Moodle forums to promote collaboration and exchange of ideas among postgraduates in a federal university. The authors contend that two factors contributed to 
the success of these learning experiences mediated through Moodle: first, the postgraduates' high level of digital literacy, which allowed them to make the most of the tools available in the digital learning environment; second, the fact that they all seemed to acknowledge the usefulness of this learning environment, its potential for promoting collaborative learning through an active engagement in forum debates and the relevance of their colleagues' posts in the forum - in other words, it appears that, in their studies, the postgraduates strongly felt like part of a powerful community of both practice and learning (WENGER, 1999). This feeling may have been intensified by the fact that Moodle was used as a complement to the weekly lessons that these postgraduates attended in face-to-face, classroom settings, unlike the PARFOR, which is an entirely online course in this federal university. This raises a number of questions which might be worth pursuing in order to maximise the opportunities for critical literacy development in distance education: Can communities of practice and learning be formed and maintained in formal distance learning programmes? If so, how? Bearing in mind the existence of distance learning programmes combining both online and classroom interaction - including PARFOR courses offered by other Brazilian federal universities - we could wonder whether such programmes are more effective in creating strong communities of learning than those conducted completely online. In the case of the teaching practicum, perhaps the implementation of a face-toface learning component might have helped to raise students' awareness of a number of questions of crucial importance in the effectiveness of this third module of the teaching practicum and the success of the course as a whole, namely: the purposes and goals of the teaching practicum in initial teacher education programmes, as well as the importance of a critical literacy perspective in such programmes. After all, if our PARFOR students are to develop the characteristics expected of them by the end of the course, which were outlined above, such as: the intellectual autonomy to develop a sociohistorical view of teaching so as to become a critical, ethical and creative professional, who is able to understand, act upon and change reality; the ability to establish relationships based on cooperation and solidarity; and the ability to understand the demands of social groups and communities in relation to socioeconomic, cultural, political and organizational problems, among other characteristics, it is possible to assume that critical literacy can play a significant role in such distance learning programmes. 


\section{References}

BELLONI, M. L. Ensaio sobre a educação a distância no Brasil. Educação \& Sociedade, ano XXIII, n. 78, p.117-142, 2002.

BRAGA, D. B. Ambientes Digitais. Reflexões teóricas e práticas. São Paulo: Cortez Editora, 2014. 152p.

COPE, B.; KALANTZIS, M. Literacies. New York: Cambridge University Press, 2012. 454p.

FREIRE, P. Pedagogia do oprimido. 42. ed. Rio de Janeiro: Paz e Terra, 2005. 253p.

GEE, J. P. What videogames have to teach us about learning and literacy. New York: Palgrave MacMillan, 2003. 256p.

GEE, J. P. An Introduction to discourse analysis. Theory and Method. London and New York: Routledge, 2010. 224p.

KNOBEL, M.; LANKSHEAR, C. New literacies. Everyday practices and social learning. Berkshire: Open University Press, 2011. 296p.

LANKSHEAR, C.; SNYDER, I.; GREEN, B. Teachers and technoliteracy. Managing literacy, technology and learning in schools. St. Leonards: Allen \& Unwin, 2000. 200p.

PAIVA, V. L. M. O. O papel da educação a distância na política de ensino de línguas. In: MENDES et al. (Org.). Revisitações: edição comemorativa: 30 anos da Faculdade de Letras/UFMG. Belo Horizonte: UFMG, 1999.

PAIVA, V. L. M. O. O uso da tecnologia no ensino de línguas estrangeiras: breve retrospectiva histórica. In: JESUS, D. M. de; MACIEL, R. F. (Org.). Olhares sobre tecnologias digitais: linguagens, ensino, formação e prática docente. Campinas: Pontes Editores, 2015. (Coleção Novas Perspectivas em Linguística Aplicada, v. 44, p. 21-34).

RIBAS, F. C.; TAGATA, W. M. A plataforma Moodle na pós-graduação: duas experiências de uso de fóruns de discussão. In: JESUS, D. M. de; MACIEL, R. F. (Org.) Olhares sobre tecnologias digitais: linguagens, ensino, formação e prática docente. Campinas: Pontes Editores, 2015. (Coleção Novas Perspectivas em Linguística Aplicada, v. 44, p.355-381).

SNYDER, I. Silicon literacies. Communication, innovation and education in the electronic age. London and New York: Routledge, 2002. 203p.

SOUZA, L. M. T. M. CMC, Hibridismos e tradução cultural: reflexões. Trabalhos em Linguistica Aplicada, v. 46, p.9-18, 2007. 
SOUZA, L. M. T. M. O professor de inglês e os letramentos no século XXI: métodos ou ética? In: JORDÃO, C. M.; MARTINEZ, J. Z; HALU, R. C. (Org.). Formação "desformatada". Práticas com professores de língua inglesa. Campinas: Pontes Editores, 2011. p.279-303.

WENGER, E. Communities of practice. Learning, meaning and identity. Cambridge: Cambridge University Press, 1999. 336p.

Data de submissão: 27/02/ 2016. Data de aprovação: 29/03/2016. 